\title{
Influence of leptin on in vitro maturation and steroidogenic secretion of cumulus-oocyte complexes through JAK2/STAT3 and MEK $1 / 2$ pathways in the rabbit model
}

\author{
M Arias-Álvarez, R M García-García, L Torres-Rovira ${ }^{1}$, A González-Bulnes ${ }^{1}$, P G Rebollar ${ }^{2}$ \\ and P L Lorenzo \\ Departamento de Fisiología (Fisiología Animal), Facultad de Veterinaria, Universidad Complutense de Madrid, \\ Ciudad Universitaria, s/n, 28040 Madrid, Spain, ${ }^{1}$ Departamento de Reproducción Animal y Conservación de \\ Recursos Zoogenéticos, INIA, Avda. Puerta de Hierro s/n, 28040 Madrid, Spain and ${ }^{2}$ Departamento de Producción \\ Animal, ETSI Agrónomos, Universidad Politécnica de Madrid, Ciudad Universitaria, s/n, 28040 Madrid, Spain
}

Correspondence should be addressed to P L Lorenzo; Email: plorenzo@vet.ucm.es

\begin{abstract}
Extreme body mass indexes may impair reproductive outcome in assisted reproductive technologies. Leptin reflects the amount of body fat and could act as a modulator of oocyte quality through activation of specific transcription factors. The aim of this work was to establish whether: 1) leptin influences meiotic and cytoplasmic oocyte maturation; 2) STAT3 and MAPK mediate the effects of leptin and 3) leptin modulates steroid secretion by cumulus-oocyte complexes (COC) during in vitro maturation (IVM). We confirmed immunolocalisation of leptin receptor in oocytes, cumulus/granulosa cells during the peri-ovulatory period. The confocal study showed that COC supplemented with 1, 10 and $100 \mathrm{ng} / \mathrm{ml}$ leptin had a significantly higher metaphase II (MII) percentage than those IVM without leptin $(P<0.05)$ and a similar MII index compared to the group supplemented with $10 \%$ FCS. Leptin did not increase the percentage of cytoplasmically matured oocytes in terms of cortical granule migration rate, whereas a significantly higher index was found in the FCS group $(\boldsymbol{P}<\mathbf{0 . 0 0 1})$. Oestradiol concentrations in spent media were higher in the FCS group compared to other treatments $(\boldsymbol{P}<\mathbf{0 . 0 0 1})$. Leptin-stimulated nuclear oocyte maturation was significantly impaired when leptin-induced JAK2/STAT3 and MEK $1 / 2$ activation was suppressed by the inhibitors $(P<0.001)$. Steroid secretion of COC was not affected by leptin activation of JAK2/STAT3 or MEK 1/2 pathways. In conclusion, JAK2/STAT3 and MEK 1/2 pathways mediate the enhancement of nuclear oocyte maturation by leptin; however, neither cytoplasmic oocyte maturation nor steroidogenic response of COC were improved in the present rabbit model.
\end{abstract}

Reproduction (2010) 139 523-532

\section{Introduction}

Obesity is a rising health problem commonly associated with infertility (Denison 2009) which may impair the outcome of assisted reproductive technologies. Studies performed with infertile women and animals indicate that the optimisation of ovary function is fundamental in the fertility prognosis (Bellver 2006). Different endocrine factors related to the body mass index may affect oocyte quality and therefore reproductive success. Thus, leptin, a $16 \mathrm{kDa}$ peptide hormone encoded by LEP (previously known as the obese gene, $O B$ ) and secreted mainly by the adipose tissue, plays an important role in the regulation of food intake, energy expenditure and reproductive success (Keim et al. 1998, Cervero et al. 2006). In fact, a minimum level of leptin is required for maintenance of the reproductive function (Cheung et al. 1997), but high leptin concentrations associated with obesity itself or polycystic ovarian syndrome have been reported to explain partially the negative impact of these pathologies on fertility (Bellver 2006).

Leptin influence on reproduction is mediated by the regulation of the hypothalamus-pituitary axis and the ovarian function through its receptor (Chehab et al. 1996, Brecchia et al. 2006). Earlier studies showed that mice lacking either leptin $(O B / O B)$ or leptin receptors $(D B / D B)$ are both obese and infertile (Zhang et al. 1994, Lee et al. 1996), whereas administration of exogenous leptin has the ability to restore fertility in these animals (Chehab et al. 1996). In the ovary, leptin receptor (LEPR, previously known as OBR) has been detected in granulosa cells of follicles, cumulus cells and oocytes in several species (human: Cioffi et al. 1997; mouse: Antczak \& Van Blerkom 1997; mouse: Ryan et al. 2002; pig: Craig et al. 2004; rabbit: Zerani et al. 2004; ewe: Muñoz-Gutiérrez et al. 2005; cattle: Paula-Lopes et al. 2007). The LEPR is a 
member of the class-I cytokine receptor superfamily with six known isoforms (Tartaglia et al. 1995, Lee et al. 1996). Both long $\left(\mathrm{LEPR}_{\mathrm{b}}\right)$ and short transmembrane isoforms $\left(\mathrm{LEPR}_{\mathrm{a}, \mathrm{c}, \mathrm{d}, \mathrm{f}}\right)$ contain identical extracellular and transmembrane domain, but the cytoplasmic region is different in length (Frühbeck 2006). LEPR usually activates cytoplasmic JAK2 to transmit leptin signals (Frühbeck 2006). LEPR $\mathrm{b}_{\mathrm{b}}$ is highly expressed in the hypothalamus and mediates leptin signalling through activation of both the STAT3 and MAPK (Tartaglia et al. 1995, Lee et al. 1996, Bjørbaek et al. 1997). The short isoforms of the receptor are more widely expressed in peripheral tissues and are capable of signalling through the MAPK pathway (Bjørbaek et al. 1997, Tartaglia 1997). Specifically, MAPK kinases 1-2 (MEK1 and MEK2) are dual-specific protein kinases involved in a MAPK cascade and appear as predominant MAPK in cumulus-oocyte complexes (COC) during in vitro maturation (IVM) in heifers (Van Tol et al. 2008). Although leptin may be integrated in a complex intracellular cross-talk system that regulates specific cell functions (Zhang et al. 1994), there is scarce information about the role of leptin through these pathways in the oocyte of humans and other animal species. In this sense, it is known that human COC are capable to respond to leptin during pre-ovulatory period (Cioffi et al. 1997), and its potential direct effects on oocyte maturation, mainly as a modulator of the oocyte fertility potential, could be through activation of specific transcription factors.

Additionally, interactions between leptin and cumulus cell-enclosed oocytes could modulate steroid production in cumulus cells (Karamouti et al. 2003, Ruiz-Cortés et al. 2003, Swain et al. 2004). It has been reported that follicular cells control oocyte physiology by secreting steroids (Mingoti et al. 1995). Therefore, concentrations of oestradiol $\left(\mathrm{OE}_{2}\right)$ and progesterone $\left(\mathrm{P}_{4}\right)$ during the peri-ovulatory period could be implicated in normal meiotic and cytoplasmic oocyte maturation by paracrine or autocrine pathways (Kaji et al. 1987, Younis et al. 1989, Andersen 1993, Tesarik \& Mendoza 1997). However, elucidation of leptin's role in such processes has been challenging, with conflicting results reported by several investigators. Understanding these mechanisms is essential because the influence of leptin on oocyte maturation ability has important implications for ovulation induction and could be helpful to find optimal hormone combinations to apply in animal and human infertility therapies.

Rabbits are widely used as an in vitro model in experimental procedures on mammalian oocytes and embryos. As a consequence, taking all these findings together and for the first time in the rabbit oocyte, the objective of this study after the immunolocalisation of the leptin receptor (LEPR) in the ovary throughout the peri-ovulatory period was to investigate: 1) the direct role of different leptin concentrations on meiotic and cytoplasmic in vitro oocyte maturation;
2) the JAK2/STAT3 and MEK 1/2 leptin-dependent intracellular mechanisms by specific pathway inhibition; 3) the steroidogenic response of COC to leptin during the oocyte maturation process.

\section{Results}

\section{Immunolocalisation of leptin receptor (LEPR)}

Positive immunostaining for LEPR was found in oocytes, cumulus cells and granulosa cells of the follicles at all stages of development in all time points measured during the peri-ovulatory period (Fig. 1). Stroma and corpora lutea exhibited high immunoreactivity for LEPR as well. Theca interna cells showed moderate immunostaining, whereas LEPR was not immunolocalised in theca externa cells. Control tissue samples showed no positive staining.

\section{Effect of leptin on nuclear and cytoplasmic oocyte maturation}

As shown in Table 1, nuclear oocyte IVM was significantly improved $(P<0.005)$ when leptin was added to the culture media at all concentrations tested $(1,10,100 \mathrm{ng} / \mathrm{ml})$ compared with the group without leptin. Groups 1 Lep, 10 Lep and 100 Lep showed similar percentages of metaphase II (MII) compared with the group cultured with FCS. Groups supplemented with 1 and $10 \mathrm{ng} / \mathrm{ml}$ leptin showed a lower rate of metaphase I (MI) compared with 0 Lep and FCS groups $(P<0.05)$.
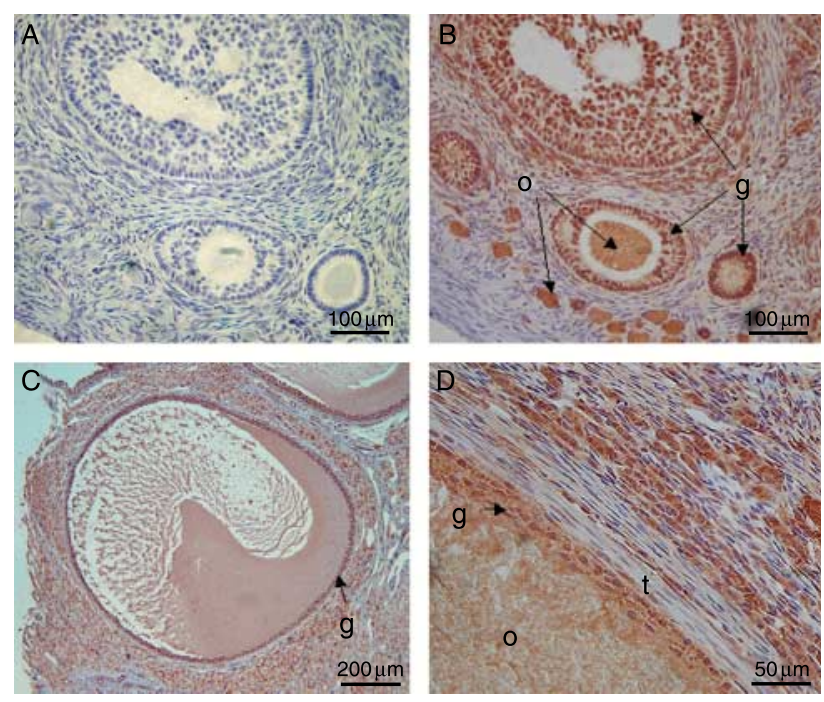

Figure 1 Immunolocalisation of leptin receptor (LEPR) in ovarian sections of rabbit does during the peri-ovulatory period. (A) Negative control. (B) Positive staining of LEPR in oocytes and granulosa cells of primordial, primary and secondary follicles. (C) Antral follicle with staining of LEPR in granulosa cells. (D) Immunodetection detail of LEPR in granulosa and theca cells. Theca externa cells show negative immunostaining (o, oocyte; g, granulosa cells; $t$, theca cells). 
Table 1 Meiotic and cytoplasmic configuration percentages, in terms of cortical granule (CG) migration, observed in rabbit oocytes at $16 \mathrm{~h}$ maturation time following the use of different leptin concentrations.

\begin{tabular}{|c|c|c|c|c|c|}
\hline & $\begin{array}{c}\mathbf{0} \mathbf{~ n g} / \mathbf{m l} \text { leptin } \\
(0 \text { Lep })\end{array}$ & $\mathbf{1} \mathbf{~ n g / m l ~ l e p t i n}$ & $\begin{array}{l}\mathbf{1 0} \mathbf{~ n g / m l ~ l e p t i n ~} \\
\text { (10 Lep) }\end{array}$ & $\begin{array}{c}\mathbf{1 0 0} \mathbf{~ n g / m l ~ l e p t i n} \\
(100 \text { Lep })\end{array}$ & $\begin{array}{c}\mathbf{1 0} \% \text { FCS } \\
\text { (FCS) }\end{array}$ \\
\hline \multicolumn{6}{|l|}{ Nuclear maturation (\%) } \\
\hline Metaphase II & $54.05^{\mathrm{a}}$ & $79.35^{\mathrm{b}}$ & $75.19^{b}$ & $66.38^{\mathrm{b}}$ & $71.62^{\mathrm{b}}$ \\
\hline Metaphase I & $19.8^{\mathrm{c}}$ & $5.4^{\mathrm{d}}$ & $7.8^{\mathrm{d}}$ & $11.2^{\mathrm{c}, \mathrm{d}}$ & $17.6^{\mathrm{C}}$ \\
\hline Germinal vesicle & 17.1 & 15.2 & 14.0 & 25.0 & 18.9 \\
\hline Abnormal chromosome configuration & $9.0^{\mathrm{d}}$ & $0.0^{\mathrm{C}}$ & $3.1^{\mathrm{c}, \mathrm{d}}$ & $7.8^{\mathrm{d}}$ & $9.5^{\mathrm{d}}$ \\
\hline \multicolumn{6}{|l|}{ Cytoplasmic maturation (\%) } \\
\hline Peripheral distribution of CG & $7.9^{c}$ & $9.3^{\mathrm{c}}$ & $10.0^{\mathrm{C}}$ & $2.9^{\mathrm{c}}$ & $25.7^{\mathrm{d}}$ \\
\hline Cortical distribution of CG & $6.3^{\mathrm{c}, \mathrm{d}}$ & $23.3^{\mathrm{c}}$ & $8.3^{\mathrm{c}, \mathrm{d}}$ & $20.0^{c, d}$ & $2.9^{\mathrm{d}}$ \\
\hline Homogeneous distribution of CG & 82.5 & 60.5 & 81.7 & 77.1 & 68.6 \\
\hline Abnormal distribution of CG & 3.2 & 7.0 & 0.0 & 0.0 & 2.9 \\
\hline
\end{tabular}

Values are mean \pm S.E.M. Means in rows with different letters differ: ${ }^{\mathrm{a}, \mathrm{b}}(P<0.005)^{\mathrm{c}, \mathrm{d}}(P<0.05)$.

Peripheral and cortical distribution of cortical granule (CG) migration (Table 1) was similar for all experimental leptin groups. However, the group supplemented with FCS showed a significantly higher number of cytoplasmically matured oocytes compared to the treatments without serum $(P<0.05)$. No significant differences were found in the percentage of oocytes with homogeneous and abnormal CG distribution between groups.

\section{STAT3 and MAPK leptin-associated signal transduction during IVM}

Leptin-stimulated nuclear oocyte maturation in terms of MII rate was significantly impaired $(P<0.001)$ when specific JAK2/STAT3 and MEK $1 / 2$ inhibitors at all concentrations tested were added to the maturation media (Tables 2 and 3 respectively). The percentage of $\mathrm{Ml}$ and germinal vesicle (GV) was increased in the $10 \mathrm{ng} / \mathrm{ml}$ leptin groups supplemented with both the inhibitors. The addition of both inhibitors in the 0 Lep group did not modify MII, MI, GV and abnormal nuclear configuration proportion. The percentage of cytoplasmically matured oocytes was similar in both the leptin IVM media supplemented with JAK2/STAT3 and MEK 1/2 inhibitors (Tables 2 and 3 respectively) and the respective control groups (0 Lep and 10 Lep). The groups supplemented with leptin and $100 \mu \mathrm{M}$ JAK2/STAT3 or $50 \mu \mathrm{M}$ MEK 1/2 inhibitor concentrations showed a significant increase in the number of oocytes with abnormal distribution of CG migration $(P<0.05)$.

\section{Steroidogenic response of $\mathrm{COC}$}

As shown in Table 4, mean $\mathrm{OE}_{2}$ secretion by $\mathrm{COC}$ was significantly higher in the FCS group compared to those oocytes cultured in media supplemented with $0,1,10$ and $100 \mathrm{ng} / \mathrm{ml}$ leptin $(P<0.005)$. No significant differences were found in $\mathrm{P}_{4}$ concentrations at the end of the IVM period between treatments.

Mean $\mathrm{OE}_{2}$ and $\mathrm{P}_{4}$ secretions by $\mathrm{COC}$ were similar when JAK2/STAT3 inhibitors were added to the IVM media compared to the respective control groups. When MEK $1 / 2$ inhibitors were added, a significant increase in the mean $\mathrm{OE}_{2}$ secretion by $\mathrm{COC}$ was observed in the $0 / 10,0 / 50$ and $10 / 10$ groups as well as similar increases in $\mathrm{P}_{4}$ secretion in $10 / 10$ and $10 / 50$ groups compared to the treatment with 0 and $10 \mathrm{ng} / \mathrm{ml}$ leptin $(P<0.05$; Table 5).

Table 2 Meiotic and cytoplasmic configuration percentages, in terms of cortical granule (CG) migration, observed in rabbit oocytes matured in vitro with 0 or $10 \mathrm{ng} / \mathrm{ml}$ leptin media plus JAK2/STAT3 inhibitors (AG490) at different concentrations.

\begin{tabular}{|c|c|c|c|c|c|c|}
\hline & $\begin{array}{l}\mathbf{0} \mathbf{~ n g} / \mathbf{m l} \\
\text { leptin } \\
(0 \text { Lep) }\end{array}$ & $\begin{array}{c}\text { 0 ng/ml } \\
\text { leptin/10 } \mu \mathrm{M} \\
\text { AG498 }(0 / 10)\end{array}$ & $\begin{array}{c}0 \mathrm{ng} / \mathrm{ml} \\
\text { leptin/100 } \mu \mathrm{M} \\
\text { AG490 }(0 / 100)\end{array}$ & $\begin{array}{c}\mathbf{1 0} \mathbf{~ n g / m l} \\
\text { leptin } \\
(10 \text { Lep) }\end{array}$ & $\begin{array}{c}10 \mathrm{ng} / \mathrm{ml} \\
\text { leptin/10 } \mathrm{MM} \\
\text { AG490 }(10 / 10)\end{array}$ & $\begin{array}{c}10 \mathrm{ng} / \mathrm{ml} \\
\text { leptin/100 } \mu \mathrm{M} \\
\text { AG490 }(10 / 100)\end{array}$ \\
\hline \multicolumn{7}{|l|}{ Nuclear maturation (\%) } \\
\hline Metaphase II & 54.1 & 40.0 & 45.5 & $75.2^{\mathrm{a}}$ & $38.7^{\mathrm{b}}$ & $45.9^{\mathrm{b}}$ \\
\hline Metaphase I & 19.8 & 24.0 & 30.3 & $7.8^{\mathrm{a}}$ & $25.3^{\mathrm{b}}$ & $17.6^{\mathrm{a}, \mathrm{b}}$ \\
\hline Germinal vesicle & 17.1 & 24.0 & 18.2 & $14.0^{\mathrm{a}}$ & $33.3^{\mathrm{b}}$ & $27.0^{\mathrm{b}}$ \\
\hline Abnormal chromosome configuration & 9.0 & 12.0 & 6.1 & 3.1 & 2.7 & 8.1 \\
\hline \multicolumn{7}{|l|}{ Cytoplasmic maturation (\%) } \\
\hline Peripheral distribution of CG & 7.9 & 11.8 & 17.6 & $10.0^{\mathrm{c}, \mathrm{d}}$ & $17.1^{\mathrm{c}}$ & $2.2^{\mathrm{d}}$ \\
\hline Cortical distribution of CG & 6.3 & 23.5 & 14.7 & 8.3 & 17.1 & 17.8 \\
\hline Homogeneous distribution of CG & 82.5 & 64.7 & 67.6 & $81.7^{\mathrm{c}}$ & $58.5^{\mathrm{d}}$ & $64.4^{\mathrm{c}, \mathrm{d}}$ \\
\hline Abnormal distribution of CG & 3.2 & 0.0 & 0.0 & $0.0^{\mathrm{c}}$ & $7.3^{\mathrm{c}, \mathrm{d}}$ & $15.6^{\mathrm{d}}$ \\
\hline
\end{tabular}

Values are mean \pm S.E.M. Means in rows with different letters differ: ${ }^{a, b}(P<0.005)^{c, d}(P<0.05)$. 
Table 3 Meiotic and cytoplasmic configuration percentages, in terms of cortical granule (CG) migration, observed in rabbit oocytes matured in vitro with 0 or $10 \mathrm{ng} / \mathrm{ml}$ leptin media plus MEK 1/2 inhibitors (PD98059) at different concentrations.

\begin{tabular}{|c|c|c|c|c|c|c|}
\hline & $\begin{array}{l}\mathbf{0} \mathbf{~ n g} / \mathbf{m l} \\
\text { leptin } \\
(0 \text { Lep })\end{array}$ & $\begin{array}{c}\text { 0 ng/ml } \\
\text { leptin/10 } \mu \mathrm{M} \\
\text { PD98059 }(0 / 10)\end{array}$ & $\begin{array}{c}\mathbf{0 n g} / \mathbf{m l} \\
\text { leptin/50 } \mu \mathrm{M} \\
\text { PD98059 }(0 / 50)\end{array}$ & $\begin{array}{l}\mathbf{1 0} \mathbf{~ n g / m l} \\
\text { leptin } \\
(10 \text { Lep })\end{array}$ & $\begin{array}{c}10 \mathrm{ng} / \mathrm{ml} \\
\text { leptin/10 } \mathrm{\mu M} \\
\text { PD98059 }(10 / 10)\end{array}$ & $\begin{array}{c}10 \mathrm{ng} / \mathrm{ml} \\
\text { leptin/50 } \mathrm{mM} \\
\text { PD98059 }(10 / 50)\end{array}$ \\
\hline \multicolumn{7}{|l|}{ Nuclear maturation (\%) } \\
\hline Metaphase II & 54.1 & 51.4 & 54.4 & $75.2^{\mathrm{a}}$ & $44.1^{\mathrm{b}}$ & $49.3^{\mathrm{b}}$ \\
\hline Metaphase I & 19.8 & 20.3 & 14.7 & $7.8^{\mathrm{a}}$ & $22.6^{\mathrm{b}}$ & $26.8^{\mathrm{b}}$ \\
\hline Germinal vesicle & 17.1 & 23.0 & 29.4 & $14.0^{\mathrm{C}}$ & $29.0^{d}$ & $22.5^{\mathrm{c}, \mathrm{d}}$ \\
\hline Abnormal chromosome configuration & 9.0 & 5.4 & 1.5 & 3.2 & 4.3 & 1.4 \\
\hline \multicolumn{7}{|l|}{ Cytoplasmic maturation (\%) } \\
\hline Peripheral distribution of CG & 7.9 & 7.1 & 7.5 & 10.0 & 10.5 & 9.1 \\
\hline Cortical distribution of CG & 6.3 & 12.5 & 2.5 & 8.3 & 13.2 & 11.4 \\
\hline Homogeneous distribution of CG & 82.5 & 69.6 & 87.5 & 81.7 & 76.3 & 68.2 \\
\hline Abnormal distribution of CG & 3.2 & 10.7 & 2.5 & $0.0^{\mathrm{a}}$ & $0.0^{\mathrm{a}}$ & $11.4^{\mathrm{b}}$ \\
\hline
\end{tabular}

Values are mean \pm S.E.M. Means in rows with different letters differ: ${ }^{\mathrm{a}, \mathrm{b}}(P<0.005)^{\mathrm{c}, \mathrm{d}}(P<0.05)$.

\section{Discussion}

The current work shows for the first time the effect of leptin on nuclear and cytoplasmic in vitro oocyte maturation, its underlying intracellular mechanisms and the steroidogenic response using the rabbit oocyte as a model. The results obtained demonstrate that the beneficial influence of leptin on meiotic oocyte maturation is mediated by JAK2/STAT3 and MEK $1 / 2$ pathways.

The presence of leptin and its receptor in the body is essential for reproductive function (Chehab et al. 1996). The universal distribution of leptin receptors between species and their different physiological status are due to the pleiotropic nature of leptin and the highly preserved structure of the LEPR (Tartaglia et al. 1995, Bjørbaek et al. 1997). In the present study, long and short isoforms of the LEPR were immunolocalised in the rabbit oocyte, cumulus and granulosa cells of the ovarian follicles at all stages of development, as well as in theca interna, estroma and corpus luteum cells during the periovulatory period. These findings corroborate those obtained in ovaries of several species (human: Karlsson et al. 1997; rat: Zamorano et al. 1997; mouse: Matsuoka et al. 1999; gilt: Lin et al. 2000, Craig et al. 2004; cattle: Thorn et al. 2007), including pseudo-pregnant rabbits (Zerani et al. 2004), and contribute to the significant body of evidence around the physiological relevance of this hormone, especially in the ovary and during the pre-ovulatory period (Cioffi et al. 1997, Duggal et al. 2002, Archanco et al. 2003).

Oocyte maturation is an essential physiological event for species survival; thus, leptin influence in oocyte quality is of keen clinical interest and potentially important for IVF protocols. In the present work, we have demonstrated that leptin enhances in vitro meiotic oocyte maturation. However, controversial results have been reported in the literature. In some species, leptin seems to promote rearrangement of cytoskeletal elements (Suzuki et al. 2010) that are involved in chromosome segregation and in processes of organelle movement (Sun \& Schatten 2006). Other studies have reported that leptin enhances an appropriate spindle assembly during metaphase (Jin et al. 2009) and stimulates meiotic oocyte maturation in mouse (Matsuoka et al. 1999), pig (Craig et al. 2004, Kun et al. 2007, Zhang et al. 2007) and cattle (Paula-Lopes et al. 2007, Van Tol et al. 2008). Nevertheless, Ryan et al. (2002) showed that leptin only induced meiotic resumption when the oocyte was cultured within its normal follicular environment. Other authors have even reported that leptin had no effect on meiotic resumption and development to MII (mouse: Swain et al. 2004; pig: Suzuki et al. 2010).

Regarding cytoplasmic maturation, studies by Runner \& Gates (1954) observed that oocytes from $O B / O B$ leptin-deficient mice were able to undergo normal fertilisation and embryo development in vivo, although these animals were obese and showed reproductive failures (Coleman 1978, Zhang et al. 1994). This led to postulate that the sterility defect due to leptin was not in the oocytes (Swain et al. 2004). According to these findings, in the present work, leptin supplementation did not improve oocyte quality in terms of CG migration rate at the concentrations tested compared to the FCS group, which achieved the best results of cytoplasmic maturation, similar to those previously reported in rabbits by our group (Garcia-Garcia et al. 2009). This finding is

Table 4 Steroid production in rabbit cumulus-oocyte complexes (COC) at $16 \mathrm{~h}$ maturation time following the use of different leptin concentrations.

\begin{tabular}{|c|c|c|c|c|c|}
\hline & 0 ng/ml leptin (0 Lep) & 1 ng/ml leptin (1 Lep) & 10 ng/ml leptin (10 Lep) & 100 ng/ml leptin (100 Lep) & $\mathbf{1 0} \%$ FCS $(\mathrm{FCS})$ \\
\hline $\mathrm{OE}_{2} / \mathrm{COC}(\mathrm{pg} / \mathrm{ml})$ & $0.28 \pm 0.14^{\mathrm{a}}$ & $0.22 \pm 0.02^{\mathrm{a}}$ & $0.32 \pm 0.14^{\mathrm{a}}$ & $0.34 \pm 0.11^{\mathrm{a}}$ & $4.13 \pm 0.77^{b}$ \\
\hline $\mathrm{P}_{4} / \mathrm{COC}(\mathrm{ng} / \mathrm{ml})$ & $0.03 \pm 0.01$ & $0.02 \pm 0.004$ & $0.03 \pm 0.01$ & $0.03 \pm 0.01$ & $0.03 \pm 0.003$ \\
\hline
\end{tabular}

Values are mean \pm S.E.M. Means in rows with different letters differ: ${ }^{\mathrm{a}, \mathrm{b}}(P<0.005)^{\mathrm{c}, \mathrm{d}}(P<0.05)$. 
Table 5 Steroid production in rabbit cumulus-oocyte complexes (COC) at $16 \mathrm{~h}$ maturation time following the use of different concentrations of JAK2/STAT3 (AG490) and MEK 1/2 (PD98059) leptin-induced pathway inhibitors.

\begin{tabular}{|c|c|c|c|c|c|c|}
\hline & $\begin{array}{l}\mathbf{0} \text { ng/ml } \\
\text { leptin } \\
(0 \text { Lep })\end{array}$ & $\begin{array}{c}\mathbf{0} \mathbf{n g} / \mathbf{m l} \\
\text { leptin/10 } \mu \mathrm{M} \\
\text { AG498 }(0 / 10)\end{array}$ & $\begin{array}{c}\text { o ng/ml } \\
\text { leptin/100 } \mu \mathrm{M} \\
\text { AG490 }(0 / 100)\end{array}$ & $\begin{array}{l}\mathbf{1 0} \mathbf{~ n g} / \mathbf{m l} \\
\text { leptin } \\
(10 \text { Lep })\end{array}$ & $\begin{array}{c}10 \mathrm{ng} / \mathrm{ml} \\
\text { leptin/10 } \mathrm{\mu M} \\
\text { AG490 }(10 / 10)\end{array}$ & $\begin{array}{c}10 \text { ng/ml } \\
\text { leptin/100 } \mu \mathrm{M} \\
\text { AG490 (10/100) }\end{array}$ \\
\hline $\mathrm{OE}_{2} / \mathrm{COC}(\mathrm{pg} / \mathrm{ml})$ & $0.18 \pm 0.04$ & $0.23 \pm 0.11$ & $0.10 \pm 0.05$ & $0.39 \pm 0.17$ & $0.44 \pm 0.24$ & $0.14 \pm 0.05$ \\
\hline \multirow[t]{2}{*}{$\mathrm{P}_{4} / \mathrm{COC}(\mathrm{ng} / \mathrm{ml})$} & $0.03 \pm 0.01$ & $0.03 \pm 0.00$ & $0.02 \pm 0.00$ & $0.03 \pm 0.00$ & $0.06 \pm 0.03$ & $0.02 \pm 0.00$ \\
\hline & $\begin{array}{l}\mathbf{0} \mathbf{~ n g} / \mathbf{m l} \\
\text { leptin } \\
(0 \text { Lep) }\end{array}$ & $\begin{array}{c}\text { 0 ng/ml } \\
\text { leptin/10 } \mathrm{\mu M} \\
\text { PD98059 }(0 / 10)\end{array}$ & $\begin{array}{c}\mathbf{0 ~ n g / m l} \\
\text { leptin/50 } \mathrm{\mu M} \\
\text { PD98059 }(0 / 50)\end{array}$ & $\begin{array}{c}\mathbf{1 0} \mathbf{~ n g} / \mathbf{m l} \\
\text { leptin } \\
(10 \text { Lep })\end{array}$ & $\begin{array}{c}10 \mathrm{ng} / \mathrm{ml} \\
\text { leptin/10 } / \mathrm{M} \\
\text { PD98059 }(10 / 10)\end{array}$ & $\begin{array}{c}10 \mathrm{ng} / \mathrm{ml} \\
\text { leptin/50 } \mathrm{\mu M} \\
\text { PD98059 }(10 / 50)\end{array}$ \\
\hline $\mathrm{OE}_{2} / \mathrm{COC}(\mathrm{pg} / \mathrm{ml})$ & $0.05 \pm 0.01^{\mathrm{a}}$ & $0.10 \pm 0.02^{b}$ & $0.11 \pm 0.01^{\mathrm{b}}$ & $0.04 \pm 0.01^{\mathrm{a}}$ & $0.13 \pm 0.02^{b}$ & $0.07 \pm 0.01^{\mathrm{a}}$ \\
\hline $\mathrm{P}_{4} / \mathrm{COC}(\mathrm{ng} / \mathrm{ml})$ & $0.02 \pm 0.00$ & $0.03 \pm 0.01$ & $0.05 \pm 0.00$ & $0.01 \pm 0.00^{\mathrm{a}}$ & $0.04 \pm 0.00^{b}$ & $0.05 \pm 0.01^{b}$ \\
\hline
\end{tabular}

Values are mean \pm S.E.M. Means in rows with different letters differ: ${ }^{a, b}(P<0.05)$.

consistent with that obtained by Paula-Lopes et al. (2007). These authors found a similar proportion of polispermic oocytes when bovine COC were supplemented with leptin or not in IVM media. However, other studies have suggested that leptin only may exert its effect when it is added in vitro at very high concentrations (500-1000 ng/ml), inhibiting microfilament reorganisation in pigs (Suzuki et al. 2010) or improving cytoplasmic maturation in cattle (Van Tol et al. 2008). In turn, these results are not in agreement with the findings obtained by other authors, in which much lower leptin concentrations $(1-100 \mathrm{ng} / \mathrm{ml})$ resulted in an increase of developmental competence related to an improvement of oocyte cytoplasmic maturation (bovine: Boelhauve et al. 2005; pig: Craig et al. 2004, Jin et al. 2009). These apparently controversial IVM results reported in the literature are probably dependent on the culture medium used or the species studied. The experiments described in the present work and in Van Tol et al. (2008) were performed in a serum-free medium in absence of any growth factor or hormone other than leptin. However, the other studies usually added gonadotropins, growth factors or follicular fluid to culture media; these additives could have enhanced the sensitivity of COC to leptin or its pathways, showing different responses at lower concentrations. Thus, possible interactions between them and oocyte maturation remain unclear. Further standardised studies are warranted, since leptin may affect oocyte quality, mediating the action of other drugs used in the stimulation protocols of fertility treatments.

The development potential of oocytes is also influenced by the synthesis and release of cumulus- and oocyte-derived factors as steroids (Andersen 1993). Measurements of steroids at the end of the maturation period are commonly used to assess the steroidogenic capacity of COC (Lorenzo et al. 1997, Mingoti et al. 2002, Shirazi \& Moalemian 2007). In this sense, the present work shows that leptin, in a serum-free culture medium, did not exert a short-term effect on the final $\mathrm{OE}_{2}$ and $\mathrm{P}_{4}$ concentrations of COC in a dose-dependent manner. Therefore, under our experimental conditions, in rabbit oocytes, leptin stimulation of meiotic maturation is not mediated by an increase of steroid secretion by COC in vitro. Our results agree with previous reports showing that $\mathrm{OE}_{2}$ and $\mathrm{P}_{4}$ do not seem to play a decisive role in oocyte meiotic maturation in vitro (Dode \& Graves 2002, Lucidi et al. 2003, Wang et al. 2006). However, contradictory findings exist about stimulatory or inhibitory effects of leptin on steroidogenesis (Zachow \& Magoffin 1997, Tsai et al. 2002, Catalano et al. 2003, Ruiz-Cortés et al. 2003, Swain et al. 2004). $\mathrm{OE}_{2}$ secreted by cumulus cells could induce a rapid increase in free intracellular calcium concentration, a mechanism that improves cytoplasmic maturation (bovine: Younis et al. 1989; human: Tesarik \& Mendoza 1997). Also, in bovine oocytes, $\mathrm{OE}_{2}$ probably participates in the formation of the polispermic block via CGs (Karlach 1987). This finding is consistent with the increase of the CG migration rate in the FCS group showed in this study, but not in the rest of the leptin groups.

Leptin acts as modulator of oocyte maturation through activation of specific transcription factors. The current work provides the first evidence that leptin uses both JAK2/STAT3 and MEK 1/2 pathways to improve meiotic IVM of rabbit oocytes in agreement with previous results in other species (mouse: Matsuoka et al. 1999; pig: Craig et al. 2004). Matsuoka et al. (1999) first suggested that the function of leptin during nuclear oocyte maturation was due to the activation of the STAT3 signal transduction pathway. In heifers, cumulus cells seem to be more influential in leptin activity than the oocyte itself, mediating the leptin-STAT3 signals to improve oocyte meiotic maturation by the long isoform LEPR (PaulaLopes et al. 2007). Of the known LEPR isoforms, only the full length one contains the intracellular domains necessary to mediate JAK2/STAT3 and MAPK signal transduction pathways. In contrast with the findings reported by Matsuoka et al. (1999) and Paula-Lopes et al. (2007), other authors showed that leptin did not increase phosphorylated STAT3, but more phosphorylated MEK1 and MEK2 proteins were predominant in COC during IVM (Van Tol et al. 2008). In this sense, Craig et al. (2004) 
also showed that leptin activates MAPK pathway in the pig oocyte. MAPK enhance maturation promoting factor activity and are involved in post-meiotic resumption events, such as spindle formation, MI to MII transition and MII arrest in several species, including rabbits ( $\mathrm{Yu}$ et al. 2002), as it was also suggested in the current work.

As we expected, this study also showed the nonsuppression of leptin-induced oocyte CG migration by JAK2/STAT3 and MEK 1/2 inhibitors. However, the increase of abnormal distribution when media were supplemented with leptin and the higher JAK2/STAT3 and MEK $1 / 2$ inhibitor concentrations (100 and $50 \mu \mathrm{M}$ respectively) imply that the oocyte may be a more sensitive cell to higher concentrations of both inhibitors widely used in other cell studies (thymus cells: Mansour et al. 2006; endometrial cancer cells: Sharma et al. 2006; hepatocarcinoma cells: Chen et al. 2007; breast cancer cells: Saxena et al. 2007) or a non-specific effect. In agreement with our cytoplasmic maturation results, it has been reported that although leptin signalling through the STAT3 pathway is beneficial for meiotic maturation (Matsuoka et al. 1999), it does not seem essential for reproduction, at least at the oocyte level (Takeda et al. 1997). Bates et al. (2003) even showed that mice with disrupted LEPR $\mathrm{B}_{\mathrm{b}}$-STAT3 signalling were obese yet fertile. However, MAPK proteins seem to be necessary for pronuclear formation in parthenogenetically activated oocytes (Posada \& Cooper 1992, Liu et al. 1998, Ito et al. 2004) for microfilament formation and thus for organelle distribution and polarity establishment in the oocyte (Verlhac et al. 1993, Sun \& Schatten 2006). This discrepancy with our results points to a possible species-specific mode of action of the leptin system on oocyte maturation, or that the MAPK involved in some aspects of cytoplasmic maturation were other than those inhibited in this study.

On the other hand, steroid concentrations were not altered in the 0 or 10 Lep groups with or without inhibitors. This allows us to determine that, in rabbit oocytes, stimulation of meiotic maturation by leptin was not mediated by an increase of steroid secretion induced by activation of JAK2/STAT3 and MEK $1 / 2$ proteins. The higher secretion of steroids found only in some groups treated with leptin and MEK 1/2 inhibitors was unclear. Maybe some compensatory mechanisms could increase steroid secretion when leptin-induced MEK 1/2 pathway was inhibited. However, the reason for this and the potential cross-talk between JAK2/STAT3 and MAPK pathways and steroid secretion in COC units need further research.

In conclusion, the current work provides the first evidence that leptin enhances meiotic oocyte maturation through activation of both JAK2/STAT3 and MEK 1/2 pathways in the rabbit oocyte model. This beneficial effect is not observed on cytoplasmic maturation in terms of CG migration nor it is mediated by an increase of $\mathrm{OE}_{2}$ and $\mathrm{P}_{4}$ secretion by COC. These findings contribute to enhance the knowledge about the relationship between obesity/lean-associated pathologies, leptin and oocyte quality to continue optimising IVF techniques in humans and animals.

\section{Materials and Methods}

Unless otherwise stated, all chemicals were purchased from Sigma Chemical Company. Ovaries were obtained from slaughtered adult animals from the abattoir (Jumogar, SL, Tarancón, Spain). Additionally, twelve 18-week-old New Zealand $\times$ California white rabbit does (Oryctolagus cuniculus) were used for immunolocalisation of LEPR in different time points during the peri-ovulatory period. Experimental procedures were approved by the Animal Ethics Committee of the Polytechnic University of Madrid (Spain) and were in compliance with the Spanish guidelines for care and use of animals in research (BOE 2005). Animals were housed in individual flat-deck cages under a constant photoperiod of $16 \mathrm{~h}$ of light per day, a temperature of $18-22{ }^{\circ} \mathrm{C}$ and a relative humidity of $60-75 \%$ maintained by a forced ventilation system in the Polytechnic University of Madrid (Spain). Ovulation was induced by i.m. injection of $1 \mu \mathrm{g}$ buserelin (Suprafact, Hoechst Marion Roussel, SA, Madrid, Spain). Does were killed with $30 \mathrm{mg} / \mathrm{kg}$ of i.v. pentobarbital sodium (Dolethal, Vetoquinol, Alcobendas, Spain) and subjected to laparotomy in order to collect their ovaries at different time points during the periovulatory period: 1 ) before ovulation induction $(0 \mathrm{~h}, n=4) ; 2)$ $8 \mathrm{~h}$ after ovulation induction $(n=4)$; 3$) 16 \mathrm{~h}$ after ovulation induction $(n=4)$.

\section{Immunohistochemistry of leptin receptor (LEPR)}

After slide deparaffinisation and rehydration in graded alcohol, ovarian sections of each experimental group described above were heat-treated in sodium citrate solution $(\mathrm{pH} 6)$ to unmask antigen epitopes. Endogenous peroxidase activity was blocked by incubating the slides with $3 \% \mathrm{v} / \mathrm{v}$ hydrogen peroxide in methanol solution for $30 \mathrm{~min}$. Nonspecific binding of immunoglobulins was blocked with normal goat serum (1:10, sc-2043, Santa Cruz Biotechnology, Santa Cruz, CA, USA) in PBS at room temperature (RT) for 30 min. Primary antibody against LEPR (1:10, sc-8391, Santa Cruz Biotechnology) was incubated overnight at room temperature in a humidified chamber. The antibody used in this study specifically recognises long and short forms of human LEPR. In the negative control sections, incubation with primary antibody was replaced by PBS solution. After that, samples were incubated with biotinylated secondary antibody $(1: 200$, biotinylated anti-mouse $\operatorname{lgG}(\mathrm{H}+\mathrm{L})$ made in goat, Vector Laboratories, Ltd, Peterborough, UK) for $30 \mathrm{~min}$, and subsequently with the avidin-biotin complex ( $\mathrm{BBC}$ Vector Elite kit, Vector Laboratories, Burlingame, CA, USA) at RT for $30 \mathrm{~min}$. After chromogen incubation (Vector Nova RED substrate Kit for Peroxidase, Vector Laboratories), the sections were counterstained with haematoxylin, photographed and assessed under a light microscope (Olympus BX40, Hamburg, Germany). 
A

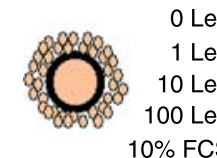

1 Lep

10 Lep $10 \%$ FCS

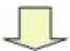

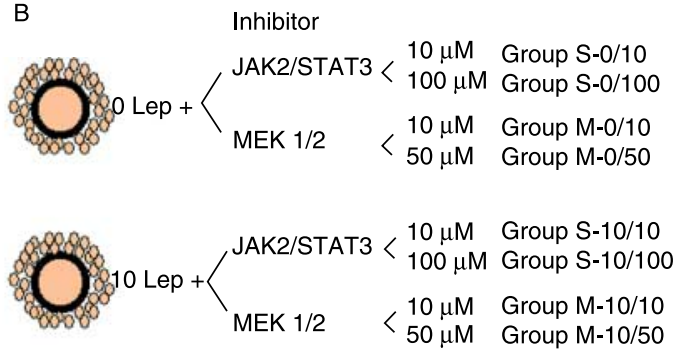

Study of nuclear and cytoplasmic oocyte maturation by confocal microscopy

Determination of steroids in spent maturation media

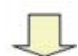

Study of nuclear and cytoplasmic oocyte maturation by confocal microscopy

Determination of steroids in spent maturation media
Figure 2 Experimental design scheme of oocyte in vitro maturation studies. (A) In vitro maturation with different concentrations of leptin ( $\mathrm{ng} / \mathrm{ml}$ ).

(B) In vitro maturation with 0 and $10 \mathrm{ng} / \mathrm{ml}$ leptin plus JAK2/STAT3 (AG490) and MEK 1/2 (PD98059)-pathways inhibitors.

\section{Oocyte collection and IVM of COC}

Ovaries of slaughtered adult animals were placed in PBS at $37^{\circ} \mathrm{C}$ and transported to the laboratory. COC were obtained by aspiration with $2 \mathrm{ml}$ syringe and $25 \mathrm{G}$ needle from ovarian follicles $\geq 1 \mathrm{~mm}$ in size under a stereoscopic microscope. COC with compact cumulus were washed and placed in $500 \mu \mathrm{l}$ maturation medium in four-well dishes (Nunclon Surface, Nunc, Roskilde, Denmark). They were cultured for $16 \mathrm{~h}$ at $38{ }^{\circ} \mathrm{C}$ under an atmosphere of $5 \% \mathrm{CO}_{2}$ in air with maximum humidity.

Role of leptin on meiotic and cytoplasmic in vitro oocyte maturation

Six replicates were made ( $n=750$ oocytes) to assess the influence of leptin on the oocyte maturation process (Fig. 2A). The maturation medium consisted of tissue culture medium (TCM-199) with $2 \mathrm{mM}$ L-glutamine, $0.1 \mathrm{mg} / \mathrm{ml}$ sodium pyruvate, $0.3 \% \mathrm{w} / \mathrm{v}$ BSA supplemented with $0,1,10,100 \mathrm{ng} / \mathrm{ml}$ leptin or $10 \%$ v/v FCS (0 Lep, 1 Lep, 10 Lep, 100 Lep and FCS groups respectively).

\section{Assessment of JAK2/STAT3 and MEK 1/2 leptin-mediated pathways during IVM}

In order to assess if leptin acts on oocyte maturation activating STAT3 and MAPK pathways, we have performed a doseresponse study in five replicates $(n=578$ oocytes). For maturation, COC were randomly divided into two groups: control with $0 \mathrm{ng} / \mathrm{ml}$ leptin (0 Lep group) and leptin group with $10 \mathrm{ng} / \mathrm{ml}$ leptin (10 Lep group). As shown in Fig. 2B, during the whole maturation period, each group (0 Lep or 10 Lep) was further treated with different concentrations of inhibitors for JAK2/STAT3 (Tyrphostin AG490) or MEK 1/2 (PD98059, MEK1 inhibitor, Cell Signalling Technology, Inc., Beverly, MA, USA) pathways. Tyrphostin AG490 is a JAK2 protein tyrosine kinase inhibitor that inhibits leptin action, ranging from 10 to $100 \mu \mathrm{M}$ in different cell types (Mansour et al. 2006, Sharma et al. 2006, Chen et al. 2007, Saxena et al. 2007). PD98059 [2-(2-amino-3methoxyphenyl)-4h-1-benzopyran-4-one] has shown to act as a highly selective inhibitor of MEK1 activation and the MAPK cascade (Crews et al. 1992). PD98059 binds to MEK1 and prevents activation by upstream activators such as c-Raf (Rosen et al. 1994). Concentrations for inhibitory activity against MEK1 and MEK2 are 10 and $50 \mu \mathrm{M}$ respectively.

\section{Study of nuclear and cytoplasmic oocyte maturation by confocal microscopy}

After the maturation period, COC were treated for the confocal study. First, cumulus cells were removed in PBS with $2 \mathrm{mM}$ hyaluronidase by gentle pipetting. Next, oocytes were treated with $0.5 \% \mathrm{w} / \mathrm{v}$ pronase in PBS to digest the zonae pellucidae, fixed in PBS containing $4 \% \mathrm{w} / \mathrm{v}$ buffered neutral paraformaldehyde solution $(\mathrm{pH} 7.2-7.4)$ and stored in PBS. Oocytes were washed with permeabilisation solution $(0.02 \% \mathrm{v} / \mathrm{v}$ Triton $\mathrm{X}-100$ in PBS) and treated for $40 \mathrm{~min}$ with blocking solution $(7.5 \% \mathrm{w} / \mathrm{v}$ BSA in PBS). They were then incubated for $30 \mathrm{~min}$
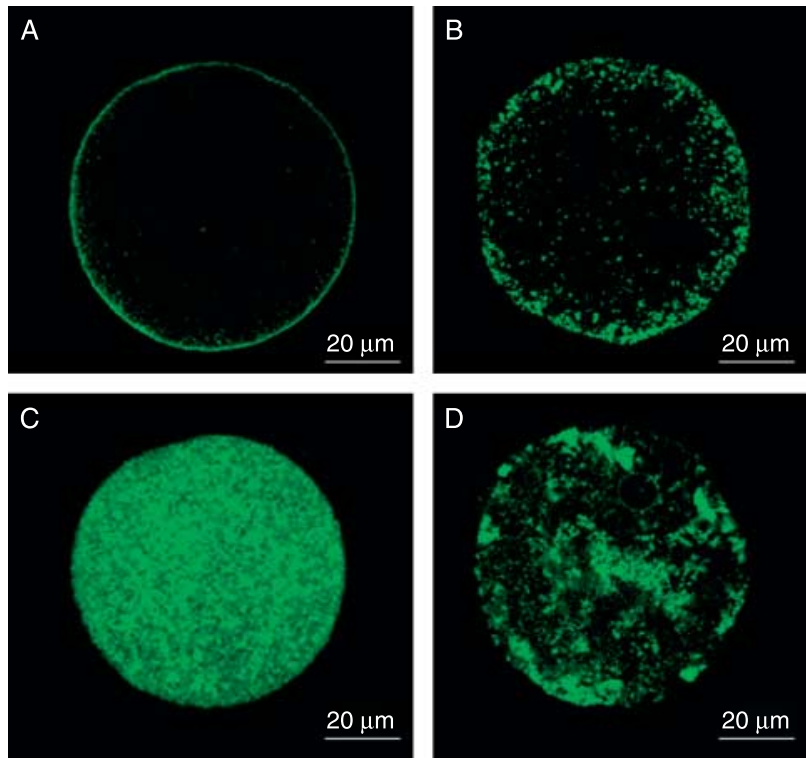

Figure 3 Cortical granule distribution in rabbit oocytes after in vitro maturation period under confocal microscopy. (A) Peripheral CG distribution. (B) Cortical distribution. (C) Homogeneous distribution. (D) Abnormal distribution. Oocyte diameter is around $80 \mu \mathrm{m}$. 
at room temperature with $100 \mu \mathrm{g} / \mathrm{ml}$ FITC of Lens culinaris for CG staining and for $15 \mathrm{~min}$ at $39{ }^{\circ} \mathrm{C}$ with $10 \mu \mathrm{g} / \mathrm{ml}$ propidium iodide for nuclear staining. After that, oocytes were mounted between a coverslip and a glass slide supported by columns of paraffin and examined under a confocal laser scanning microscope (Leica, TCS SP5, Wetzlar, Germany). Complete nuclear maturation was measured in terms of MII rate. The rest of nuclear configurations were classified as oocytes that reinitiated the meiosis process ( $\mathrm{Ml}$ index) or not (GV rate). According to a previous work (Arias-Alvarez et al. 2009), CG distribution was classified as follows (Fig. 3): A) peripheral: CG were distributed adjacent to the plasma membrane, since they were cytoplasmically matured; B) cortical: most of the CG were localised in the cortical area of oocytes, thus being considered as partially matured; C) homogeneous: CG were scattered throughout the cytoplasm, since they did not show cytoplasmic maturation; D) non homogeneous or abnormal: anomalous distribution of CG compatible with poor quality or degenerated oocytes.

\section{Determination of steroids in spent maturation media}

Spent maturation media were collected after completion of oocyte maturation period and stored at $-32{ }^{\circ} \mathrm{C}$ until analysed. Steroid concentrations were measured by ELISA based on the principle of competitive binding using a specific kit (Demeditec Diagnostics $\mathrm{GmbH}$, Kiel, Germany) for $\mathrm{OE}_{2}$ $\left(\mathrm{OE}_{2}\right.$-sensitive ELISA) and for $\mathrm{P}_{4}\left(\mathrm{P}_{4}\right.$ ELISA) quantification. Purified anti- $\mathrm{OE}_{2}$ and anti- $\mathrm{P}_{4}$ polyclonal antibodies were used. Intra- and inter-assay coefficients of variation were 5.5 and $6.8 \%$ for $\mathrm{OE}_{2}$, and 5.4 and $9.9 \%$ for $\mathrm{P}_{4}$, respectively. The assay ranges were $0-200 \mathrm{pg} / \mathrm{ml}\left(\mathrm{OE}_{2}\right)$ and $0-40 \mathrm{ng} / \mathrm{ml}\left(\mathrm{P}_{4}\right)$. Results are expressed as average $\mathrm{OE}_{2}(\mathrm{pg} / \mathrm{ml})$ and $\mathrm{P}_{4}(\mathrm{ng} / \mathrm{ml})$ concentrations produced by each COC after the IVM period.

\section{Statistical analysis}

Data were analysed using the SPSS program for Windows (SPSS 15.0, Inc., Chicago, IL, USA). $\chi^{2}$-test was carried out to compare different categories of nuclear maturation and CG migration rate between experimental groups. Mean $\mathrm{OE}_{2}$ and $\mathrm{P}_{4}$ concentrations in spent media by each COC were analysed with the ANOVA test (post-hoc was Duncan test) for the different IVM groups. All the results are expressed as the mean \pm s.E.M., and statistical significance was accepted for $P<0.05$.

\section{Declaration of interest}

The authors declare that there is no potential conflict of interest that could be perceived as prejudicing the impartiality of the research reported.

\section{Funding}

This work was supported by MEC projects AGL08-022283 and UCM-CM research program (920249-2008) and CM/FSE.

\section{Acknowledgements}

The authors wish to thank Drs J Contreras and L Revuelta for their support in the experimental part of this work.

\section{References}

Andersen CY 1993 Characteristics of human follicular fluid associated with successful conception after in vitro fertilization. Journal of Clinical Endocrinology and Metabolism 77 1227-1234.

Antczak M \& Van Blerkom J 1997 Oocyte influences on early development: the regulatory proteins leptin and STAT3 are polarized in mouse and human oocytes and differentially distributed within the cells of the preimplantaion stage embryo. Molecular Human Reproduction 3 1067-1086.

Archanco M, Muruzábal FJ, Lopiz D, Garayoa M, Gomez-Ambrosi J, Frühbeck G \& Burell MA 2003 Leptin expression in the rat ovary depends on estrus cycle. Journal of Histochemistry and Cytochemistry $\mathbf{5 1}$ 1269-1277.

Arias-Alvarez M, García-García RM, Rebollar PG, Revuelta L, Millán P \& Lorenzo PL 2009 Influence of endocrine and metabolic status on oocyte quality and follicular characteristics at different postpartum periods in primiparous rabbit does. Theriogenology 72 612-623.

Bates SH, Stearns WH, Dundon TA, Schubert M, Tso AW, Wang $Y$, Banks AS, Lavery HJ, Haq AK, Maratos-Flier E et al. 2003 STAT3 signalling is required for leptin regulation of energy balance but not reproduction. Nature $\mathbf{4 2 1} 856-859$.

Bellver J 2006 Symposium: diet, nutrition and exercise in reproduction. Obesity and assisted reproductive technology outcomes. Reproductive Biomedicine Online 12 562-568.

Bjørbaek C, Uotani S, da Silva B \& Flier JS 1997 Divergent signaling capacities of the long and short isoforms of the leptin receptor. Journal of Biological Chemistry 272 32686-32695.

Boelhauve M, Sinowatz F, Wolf E \& Paula-Lopes FF 2005 Maturation of bovine oocytes in the presence of leptin improves development and reduces apoptosis of in vitro-produced blastocysts. Biology of Reproduction 73 737-744.

Boletin Oficial del Estado (BOE) 2005 Real Decreto 1201/2005. Sobre protección de los animales utilizados para experimentación y otros fines científicosc. Boletin Oficial del Estado 252 34367-34391.

Brecchia G, Bonanno A, Galeati G, Federici G, Maranesi M, Gobbetti A, Zerani M \& Boiti C 2006 Hormonal and metabolic adaptation to fasting: effects on the hypothalamic-pituitary-ovarian axis and reproductive performance of rabbit does. Domestic Animal Endocrinology 31 105-122.

Catalano S, Marsico M, Giordano C, Mauro L, Rizza P, Panno MP \& Andò S 2003 Leptin enhances, via AP-1, expression of aromatase in the MCF-7 cell line. Journal of Biological Chemistry 278 28668-28676.

Cervero A, Domínguez F, Horcajadas JA, Quñonero A, Pellicer A \& Simón C 2006 The role of leptin in reproduction. Current Opinion in Obstetrics and Gynecology 18 297-303.

Chehab FF, Lim ME \& Lu R 1996 Correction of the sterility defect in homozygous obese female mice by treatment with the humen recombinant leptin. Nature Genetics 12 318-320.

Chen C, Chang YC, Liu CL, Liu TP, Chang KJ \& Guo IC 2007 Leptin induces proliferation and antiapoptosis in human hepatocarcinoma cell by up-regulating cyclin D1 and down-regulating Bax via a janus kinase 2-linked pathway. Endocrine-Related Cancer 14 531-529.

Cheung CC, Thornton JE, Kuijper JL, Weigle DS, Clifton DK \& Steiner RA 1997 Leptin is a metabolic gate for the onset of puberty in the female rat. Endocrinology 138 855-858.

Cioffi JA, Van Blerkom J, Antczak M, Shafer A, Wittmer S \& Snodgrass HR 1997 The expression of leptin and its receptors in pre-ovulatory human follicles. Molecular Human Reproduction 3 467-472.

Coleman DL 1978 Obese and diabetes: two mutant genes causing diabetesobesity syndromes in mice. Diabetologia 14 141-148.

Craig J, Zhu H, Dyce PW, Petrik J \& Li J 2004 Leptin enhances oocyte nuclear and cytoplasmic maturation via the mitogen-activated protein kinase pathway. Endocrinology 145 5355-5363. 
Crews CM, Alessandrini A \& Erikson RL 1992 The primary structure of MEK, a protein kinase that phosphorylates the ERK gene product. Science $\mathbf{2 5 8}$ 478-480.

Denison F 2009 Impact of obesity on maternal reproductive fitness. Proceedings of the Society for Reproduction and Fertility, Annual Conference 2009, Oxford, UK, pp 19.

Dode MAN \& Graves C 2002 Involvement of steroid hormones on in vitro maturation of pig oocytes. Theriogenology 57 811-821.

Duggal PS, Weitsman SR, Magoffin DA \& Norman RJ 2002 Expression of the long (OB-RB) and short (OB-RA) forms of the leptin receptor throughout the oestrous cycle in the mature rat ovary. Reproduction 123 899-905.

Frühbeck G 2006 Intracellular signalling pathways activated by leptin. Biochemical Journal 393 7-20.

Garcia-Garcia RM, Arias-Alvarez M, Rebollar PG, Revuelta L \& Lorenzo PL 2009 Influence of different reproductive rhythms on serum estradiol, testosterone levels, features of follicular population and atresia rate, and oocyte maturation in controlled suckling rabbits. Animal Reproduction Science 114 423-433.

Ito J, Shimada M \& Terada T 2004 Mitogen-activated protein kinase kinase inhibitor suppresses cyclin B1 synthesis and reactivation of $\mathrm{p} 34^{\mathrm{cdc} 2}$ kinase, which improves pronuclear formation rate in matured porcine oocytes activated by $\mathrm{Ca}^{2+}$ ionophore. Biology of Reproduction 70 797-804.

Jin YX, Cui XS, Han YJ \& Kim NH 2009 Leptin accelerates pronuclear formation following intracytoplasmic sperm injection of porcine oocytes: possible role for MAP kinase inactivation. Animal Reproduction Science 115 113-148.

Kaji E, Bornslaeger EA \& Schultz RM 1987 Inhibition of mouse oocyte cyclic AMP phosphodiesterase by steroid hormones: a possible mechanism for steroid hormone inhibition of oocyte maturation. Journal of Experimental Zoology 243 489-493.

Karamouti M, Kollia P, Karligiotou E, Kallitsaris A, Prapas N, Kollios G, Seferiadis K, Vamvakopoulos N \& Messinis IE 2003 Absence of leptin expression and secretion by human luteinized granulosa cells. Journal of Molecular Endocrinology 31 233-239.

Karlach V 1987 The effect of FSH, LH, oestradiol-17 beta, and progesterone on cytoplasmic maturation of bovine follicular oocytes in vitro. Folia Biologica 33 258-265.

Karlsson C, Lindell K, Svensson E, Bergh C, Lind P, Billig H, Carlsson LMS \& Carlsson B 1997 Expression of functional leptin receptors in the human ovary. Journal of Clinical Endocrinology and Metabolism 82 4144-4148.

Keim NL, Stern JS \& Havel PJ 1998 Relation between circulating leptin concentrations and appetite during a prolonged, moderate energy deficit in women. American Journal of Clinical Nutrition 68 794-801.

Kun Z, Shaohua W, Yufang M, Yankun L, Hengxi W, Xiuzhu S, Yonghui Z, Yan L, Yunping D, Lei Z et al. 2007 Effects of leptin supplementation in in vitro maturation medium on meiotic maturation of oocytes and preimplantation development of parthenogenetic and cloned embryos in pigs. Animal Reproduction Science 101 85-96.

Lee G, Proenca R, Montez JM, Carroll KM, Darvishzadeh JG, Lee JI \& Friedman JM 1996 Abnormal splicing of the leptin receptor in diabetic mice. Nature 379 632-635.

Lin J, Barb CR, Matteri RL, Kraeling RR, Chen X, Meinersmann RJ \& Rampacek GB 2000 Long form leptin receptor mRNA expression in the brain, pituitary, and other tissues in the pig. Domestic Animal Endocrinology 1 53-61.

Liu L, Ju JC \& Yang X 1998 Differential inactivation of maturationpromoting factor and mitogen-activated protein kinase following parthenogenetic activation of bovine oocytes. Biology of Reproduction 59 537-545.

Lorenzo PL, Illera JC, Silvan G, Munro CJ, Illera MJ \& Illera M 1997 Steroidlevel response to insulin-like growth factor-1 in oocytes matured in vitro. Journal of Reproductive Immunology 35 11-29.

Lucidi P, Bernabò N, Turriani M, Barboni B \& Mattioli M 2003 Cumulus cells steroidogenesis is influenced by the degree of oocyte maturation. Reproductive Biology and Endocrinology 1 1-9.

Mansour L, Pereira FG, Araujo EP, Amaral MEC, Morari J, Ferraroni NR, Ferreira DS, Lorand-Metze I \& Velloso L 2006 Leptin inhibits apoptosis in thymus through a janus kinase-2-independent, insulin receptor substrate-1/phosphatidylinositol-3 kinase-dependent pathway. Endocrinology 147 5470-5479.
Matsuoka T, Tahara M, Yokoi T, Masumoto N, Takeda T, Yamaguchi M, Tasaka K, Kurachi H \& Murata Y 1999 Tyrosine phosphorylation of STAT3 by leptin through leptin receptor in mouse metaphase 2 stage oocyte. Biochemical and Biophysical Research Communications 256 480-484.

Mingoti GZ, Garcia JM \& Rosa-e-Silva AAM 1995 The effect of serum on in vitro maturation, in vitro fertilization and steroidogenesis of bovine oocytes co-cultured with granulose cells. Brazilian Journal of Medical and Biological Research 28 213-217.

Mingoti GZ, Garcia JM \& Rosa-e-Silva AAM 2002 Steroidogenesis in cumulus cells of bovine cumulus-oocyte-complexes matured in vitro with BSA and different concentrations of steroids. Animal Reproduction Science 69 175-186.

Muñoz-Gutierrez M, Findlay PA, Adam CL, Was G, Campbell BK, Kendall NR, Khalid M, Forsberg M \& Scaramuzzi RJ 2005 The ovarian expresión of mRNAs for aromatase, IGF-I receptor, IGF binding protein$2,-4$ and -5 , leptin and leptin receptor in cycling ewes after three days of leptin infusion. Reproduction 130 869-881.

Paula-Lopes FF, Boelhauve M, Habermann FA, Sinowatz F \& Wolf E 2007 Leptin promotes meiotic progression and developmental capacity of bovine oocytes via cumulus cell-independent and -dependent mechanisms. Biology of Reproduction 8 532-541.

Posada J \& Cooper JA 1992 Requirements for phosphorylation of MAP kinase during meiosis in Xenopus oocytes. Science 255 212-215.

Rosen LB, Ginty DD, Weber MJ \& Greenberg ME 1994 Membrane depolarization and calcium influx stimulate MEK and MAP kinase via activation of Ras. Neuron 12 1207-1221.

Ruiz-Cortés ZT, Martel-Kennes Y, Gévry NY, Downey BR, Palin MF \& Murphy BD 2003 Biphasic effects of leptin in porcine granulosa cells. Biology of Reproduction 68 789-796.

Runner MN \& Gates A 1954 Conception in prepuberal mice following artificially induced ovulation and mating. Nature 174 222-223.

Ryan NK, Woodhouse CM, Van der Hoek KH, Gilchrist RB, Armstrong DT \& Norman RJ 2002 Expression of leptin and its receptor in the murine ovary: possible role in the regulation of oocyte maturation. Biology of Reproduction 66 1548-1554.

Saxena NK, Vertino PM, Anania FA \& Sharma D 2007 Leptininduced growth stimulation of breast cancer cells involves recruitment of histone acetyltranferases and mediator complex to cyclin D1 promoter via activation of stat3. Journal of Biological Chemistry $\mathbf{2 8 2}$ 13316-13325.

Sharma D, Saxena NK, Vertino PM \& Anania FA 2006 Leptin promotes the proliferative response and invasiveness in human endometrial cancer cells by activating multiple signal-transduction pathways. EndocrineRelated Cancer 13 629-640.

Shirazi A \& Moalemian Z 2007 Ovine cumulus cells estradiol-17 $\beta$ production in the presence or absence of oocyte. Animal Reproduction Science 101 125-133.

Sun QY \& Schatten H 2006 Regulation of dynamic events by microfilaments during oocyte maturation and fertilization. Reproduction 131 193-205.

Suzuki H, Sasaki Y, Shimizu M, Matsuzaki M, Hashizume T \& Kuwayama H 2010 Ghrelin and leptin did not improve meiotic maturation of porcine oocytes cultured in vitro. Reproduction in Domestic Animals [in press]. DOI: 10.1111/j.1439-0531.2009.01352.x.

Swain JE, Dunn RL, McConnell D, Gonzalez-Martinez J \& Smith GD 2004 Direct effects of leptin on mouse reproductive function: regulation of follicular, oocyte, and embryo development. Biology of Reproduction $\mathbf{7 1}$ 1446-1452.

Takeda K, Noguchi K, Shi W, Tanaka T, Matsumoto M, Yoshida N \& Kishimoto TSA 1997 Targeted disruption of the mouse Stat3 gene leads to early embryonic lethality. PNAS 94 3801-3804.

Tartaglia LA 1997 The leptin receptor. Journal of Biological Chemistry 272 6093-6096.

Tartaglia LA, Dembski M, Weng X, Deng N, Culpepper J, Devos R, Richards GJ, Campfield LA, Clark FT, Deeds J et al. 1995 Identification and expression cloning of a leptin receptor, OB-R. Cell 83 1263-1271.

Tesarik J \& Mendoza C 1997 Direct non- genomic effects of follicular steroids on maturing human oocytes: oestrogen versus androgen antagonism. Human Reproduction Update 3 95-100. 
Thorn SR, Meyer ME, Amburg EV \& Boisclair YR 2007 Effect of estrogen on leptin and expression of leptin receptor transcripts in prepuberal dairy heifers. Journal of Dairy Science 90 3742-3750.

Tsai EM, Yang CH, Chen SC, Liu YH, Chen HS, Hsu SC \& Lee JN 2002 Leptin affects pregnancy outcome of in vitro fertilization and steroidogenesis of human granulosa cells. Journal of Assisted Reproduction and Genetics 19 169-176.

Van tol HTA, Van Eerdenburg F, Colenbrander B \& Roelen BAJ 2008 Enhancement of bovine oocyte maturation by leptin is accompanied by an upregulation in mRNA expression of leptin receptor isoforms in cumulus cells. Molecular Reproduction and Development $\mathbf{7 5}$ 578-587.

Verlhac MH, Kúbiak JZ, Arlinghaus RB, Pines J \& Maro B 1993 MAP kinase becomes stably activated at metaphase and is associated with microtubule organizing centers during meiotic maturation of mouse oocytes. Developmental Biology 158 330-340.

Wang H, Isobe N, Kumamoto K, Yamashiro H, Yamashita Y \& Terada T 2006 Studies of the role of steroid hormone in the regulation of oocyte maturation in cattle. Reproductive Biology and Endocrinology 44.

Younis Al, Brackett BG \& Fayrer- Hosken RA 1989 Influence of serum and hormones on bovine oocyte maturation and fertilization in vitro. Gamete Research 23 189-201.

Yu HQ, Bou S, Chen DY \& Sun QY 2002 Phosphorilation of MAP kinase and p90rsk and its regulation during in vitro maturation of cumulus-enclosed rabbit oocytes. Zygote 10 311-316.
Zachow RJ \& Magoffin DA 1997 Direct intraovarian effects of leptin: impairement of the synergistic action of insuline-like growth factor-I, on follicle-stimulating hormone-dependent estradiol 17-b production by rat ovarian granulose cells. Endocrinology 138 847-850.

Zamorano PL, Mahesh VB, De Sevilla LM, Chorich LP, Bhat GK \& Brann DW 1997 Expression and localization of the leptin receptor in endocrine and neuroendocrine tissues of the rat. Neuroendocrinology 65 223-228.

Zerani M, Boiti C, Zampini D, Brecchia G, Dall'Aglio C, Ceccarelli P \& Gobbetti A 2004 Ob receptor in rabbit ovary and leptin in vitro regulation of corpora lutea. Journal of Endocrinology 183 279-288.

Zhang Y, Proenca R, Maffei M, Barone M, Leopold L \& Friedman JM 1994 Positional cloning of the mouse obese gene and its human homologue. Nature 372 425-432.

Zhang K, Wei HX, Zhang YH, Wang SH, Li Y, Dai YP \& Li N 2007 Effects of ghrelin on in vitro development of porcine in vitro fertilized and parthenogenetic embryos. Journal of Reproduction and Development 53 647-653.

Received 23 July 2009

First decision 24 August 2009

Revised manuscript received 10 November 2009

Accepted 23 December 2009 